\title{
Examining the Economic Burden of Out-of-Pocket Health Expenditures for Households in Different Socio-Economic Groups in Turkey ${ }^{1}$
}

Gökçe MANAVGAT (https://orcid.org/0000-0003-3729-835X), Department of International Trade and Logistics, Toros University, Turkey; e-mail: gokce.manavgat@toros.edu.tr

Fatih SAYGILI (https://orcid.org/0000-0001-8203-7904), Department of Economics, Ege University, Turkey; email: fatih.saygili@ege.edu.tr

Martine AUDIBERT (https://orcid.org/0000-0002-6187-2502), Centre d'Etudes et de Recherches sur le Développement International (CERDI), Université Clermont Auvergne, France; e-mail: martine.audibert@uca.fr

\section{Türkiye'de Farklı Ekonomik Gruptaki Hanehalkları için Cepten Yapılan Sağlık Harcamalarının Ekonomik Yükünün İncelenmesi²}

\begin{abstract}
In this study, the varying nature of catastrophic threshold for out-of-pocket health expenditures of Turkish households has been investigated by the help of Household Budget Surveys compiled by TurkStat (2002-2016). Two methods have been used in the calculation of catastrophic health expenditures: (i) The fixed (same) catastrophic thresholds and (ii) variable thresholds based on different socio-economic groups (quintile) have been calculated and compared. Also, catastrophic health expenditures risk factors have been analysed by using binary logistic regression models. Unlike previous studies, poor households have been found more likely to experience catastrophic health expenditure in Turkey. Thus, the result indicates that analyses using the same threshold level for all socio-economic groups of a society might lead policymakers to misleading conclusions.
\end{abstract}

Keywords

Catastrophic Health Expenditure, Health Financing, Out-Of-Pocket Health Expenditure, Health Policy, Financial Burden, Turkey.

JEL Classification Codes : $\quad$ C83, I10, I13, I18.

$\ddot{\mathbf{O} z}$

Bu çalışmada, TÜİK tarafından derlenen Hanehalkı Bütçe Anketleri (2002-2016) kullanılarak, Türkiye'de hanehalklarının cepten yapmış oldukları sağlık harcamalarının katastrofik düzeyi araştırılmıştır. Katastrofik sağlık harcamalarının hesaplanmasında iki yöntem kullanılmıştır. Geleneksel sabit katastrofik eşik değerleri ve daha önce Türkiye için uygulanmamış farklı sosyo ekonomik gruplar için değişim gösteren değişken eşik değerleri yaklaşımları kullanılarak analizler yapılmış ve sonuçlar karşılatılırmıştır. Ayrıca, katastrofik sağlık harcamalarında olası risk faktörleri

1 This paper is derived from the dissertation of Manavgat, G. (2018), "The Financial Burden of Out-Of-Pocket Healthcare Expenditures and Their Impacts on Different Expenditure Groups in Turkey" that prepared at Ege University Institute of Social Sciences.

2 Bu çalışma, Ege Üniversitesi Sosyal Bilimler Enstitüsü, İktisat ABD'nda hazırlanan Manavgat, G. (2018), "Türkiye'de Sağllk Hizmetleri Kullanımında Cepten Yapılan Harcamaların Finansal Yükü ve Farkl Harcama Grupları Üzerindeki Etkileri” başlıklı doktora tezinden türetilmişstir. 
Manavgat, G. \& F. Sayg1l \& M. Audibert (2020), "Examining the Economic Burden of Out-of-Pocket Health Expenditures for Households in Different Socio-Economic Groups in Turkey", Sosyoekonomi, Vol. 28(46), 25-49.

lojistik regresyon modelleri kullanılarak analiz edilmiştir. Türkiye için yapılan önceki araştırmaların aksine, bu çalışmada yoksul hanehalkları arasında katastrofik sağlık harcamalarına maruz kalma olasılığı daha yüksek olduğu belirlenmiştir. Bu sonuç, her bir farklı ekonomik grupta yer alan hanehalkları arasında aynı eşik değeri seçilerek yapılan analizlerin, harcama eşiği sonrası aynı oranda harcama yapma eğilimine sahip olacağı mantığının yanıltıcı olabileceğini dikkate almak gerektiğini ortaya koymaktadır.

Anahtar Sözcïkler $\quad$ : Katastrofik Sağlık Harcaması, Sağlık Finansman1, Cepten Sağlık Harcaması, Sağlık Politikası, Finansal Yük, Türkiye.

\section{Introduction}

Out-of-pocket (OOP) health expenditures are spending paid by households with their own resources when pre-payment mechanisms do not exist in healthcare financing or when insurance coverage is insufficient. OOP expenditures are used as direct contributions of households to countries' health systems in order to provide additional income to the public health services and to increase the effectiveness and to control demand against the moral hazard. When OOP payments are compared with tax, social insurance and prepayment healthcare mechanisms, it is considered as the most problematic health financing tool (WHO, 2000, 2005). Since the high rate of out-of-pocket healthcare payments constitute a large part of the budgets of individuals or household, they may cause catastrophe and thus increase or deepens poverty. Moreover, high OOP for healthcare may restrict access to health services especially for poor. This situation may lead to the distortion of vertical equity as it results in unfair financing in the country. As well as, increasing the prevalence of countries' access to health services, expanding of the risk share mechanism and prevention of catastrophism caused by out-of-pocket spending by expanding universal insurance coverage are extremely important. In other words, the basic principle is to provide financial protection for all as well as providing access to health service. Evidences show that in countries where pre-payment mechanisms are not developed, financial protection is not provided among households and the prevalence of catastrophic healthcare expenditures is high (Xu et al., 2003; Wagstaff \& Doorslaer, 2003; Ekman, 2004; Xu et al., 2006; Su et al., 2006; Gotsadze et al., 2009; Somkotra \& Lagrada, 2009; Minh et al., 2012; Adisa, 2015).

Turkey has introduced a dynamic process of health policies with the reforms under the Health Transformation Program (HTP) in 2003. When the HTP was put into action, it has been aimed to disseminate and improve health services and targeted to extend health insurance coverage especially for the poor in order to protect them from the financial burden. On the other hand, various cost-containment strategies have begun to be implemented through privatizations or user contributions to limit increased government health expenditures. Besides health services that are financed by general taxes and social security premiums, user contribution mechanism has begun to be implemented in Turkey in recent years in order to shift the economic burden to private sector, to earn extra income, prevent unnecessary demand and cut-off government expenditures. OOP payments are used together with pre-payment mechanisms in health financing. Co-payments were introduced for all types of outpatient care in 2009. On the one hand, increasing the extent of all the population 
Manavgat, G. \& F. Saygilı \& M. Audibert (2020), "Examining the Economic Burden of Out-of-Pocket Health Expenditures for Households in Different Socio-Economic Groups in Turkey”, Sosyoekonomi, Vol. 28(46), 25-49.

in health insurance coverage, on the other hand, the policies of increasing user contributions can create a mechanism that narrows the depth of health insurance.

The share of OOP health expenditure in total health expenditures decreased from $29.1 \%$ in 1999 to $16.8 \%$ in 2016 in Turkey. However, over the last decade, OOP health spending has continued to constitute a one-five of health financing. This rate is slightly below the EU average, but higher than countries with advanced social security system. For example, the share of OOP payments in total health expenditures is $12.4 \%$ in Germany, $15.1 \%$ in UK, $9.7 \%$ in France and $11.4 \%$ in Netherlands (World Bank, 2016). Given the relationship between the percentage of OOP payments and financial risk, it is important to analyse the economic burden of OOP health spending in Turkey. The question of what the financial risk of households is due to these expenditures is crucial for the outcomes of healthcare reform policies. Moreover, according to the Household Budget Surveys (HBS) in Turkey, it is observed that there has been a recent increase in the proportion of households that make any out-of-pocket health expenditures. While the proportion of households faced with any out-of-pocket health expenditures was $46.4 \%$ in 2002 , it reached $59.2 \%$ in 2014 (HBS, 2002-2016).

Researches done for Turkey show that the share of OOP is important for the poor (Sulkü \& Bernard, 2012). Evidence has been found that the percentage of households that catastrophically spent increased and these payments increase the potential risks of poverty with the HTP (Aran \& Hentschel, 2012; Yardım et al., 2010; Özgen et al., 2015). Tokatlığlu and Tokatlıoglu (2014) and (2018) showed that catastrophic health spending in Turkey between 2002-2014 have decreased and low capacity to create new poverty, but a high degree of deepening current poverty capacity. Erus and Aktakke (2012) investigated the impact of health insurance reforms on expenditures of public health insurance holders in Turkey for 2003-2006. They found that HTP reforms improved access to health care facilities and reduced the incidence of high health expenditures, but that these reforms were more beneficial to households with high income levels. Yereli et al. (2014) have found that financial burden of OOP does not increase with co-payment policy for 2003-2011. Yardim et al. (2013) addressed catastrophic expenditures according to insurance types and found an increased risk of catastrophe among non-poor household and public insurance holders by using data 2003, 2006 and 2009. Brown et al. (2014) found that catastrophic OOP health expenditures decreased in Turkey between 2002 and 2008, and also that the poor were less likely to incur catastrophic health expenditures because they were not in healthcare seeking behaviour.

The common feature of the previous limited number of studies is that thresholds are used fixed for all socioeconomic groups to define catastrophic in Turkey. In other words, the different denominators (i.e. capacity to pay, total expenditures or income) were used to describe catastrophic expenditures, but the fixed threshold value was taken into account for all households of different economic levels in previous studies. In this study, we consider a variable threshold value for each different socio-economic household group. When fixed threshold is taken into account for different socioeconomic groups, it is assumed that the value of the remaining expenditure is the same as the decision to spend for other needs 
Manavgat, G. \& F. Sayg1l \& M. Audibert (2020), "Examining the Economic Burden of Out-of-Pocket Health Expenditures for Households in Different Socio-Economic Groups in Turkey", Sosyoekonomi, Vol. 28(46), 25-49.

between different groups and also the benefit derived from the expenditure of the last unit is also different among the households. So, in this study, we analysed the incidence of catastrophe amongst households of different socioeconomic status quintile by using variable threshold level method suggested by Onoka et al. (2011). We think that it may be more appropriate to examine catastrophic health expenditures with variable threshold measurement for countries where socio-economic group differences are high such as Turkey. In addition, we conducted the fixed threshold values based on capacity to pay suggested by WHO and thus focused on how to vary the results from the variable thresholds. In the previous studies for Turkey, the data based on the latest 2011 was used and the impacts of general health insurance and co-payment policies implemented in 2009 on OOP health payments have been examined for short-term. For this reason, we added from data 2014 and provided some additional insight to best detect the real effects of such policy changes. Also, finally, we examined the factors related to the risk of catastrophic health payments by using binary logistic regression at the fixed threshold and variable thresholds.

\section{A Brief Overview of Recent Health Reforms and Out-of-Pocket Expenditures in Turkey}

Until 2006, there were four health insurance schemes. They were the Civil Servants Pension Fund (GERF), the Social Insurance Organization (SIO) for private sector employees and blue collar public employees, the Bağ-Kur for self-employed and the Green Card for the poor and the civil servants for active public employees whose health expenditures were financed through allocations from the government budget. In 2006, GERF, SIO and BağKur were unified under Social Security Institution (SSI) which was established in 2005 as an attached institution of the Ministry of Labour and Social Security. These policy implementations have expanded the financial risk sharing mechanism. SSI contracted with private health care facilities to increase and refine supply in health care. In 2006, the private sector was encouraged by contacted between the Social Security Institution and private health institutions, and the extra fee up to $30 \%$ for services in private hospitals was provided by SSI. Thus, the options in health services for patients were expanded as well as increasing the number of health services' providers.

Unification of health insurance schemes under the SSI was a first step for a premiumbased financing mechanism of the General Health Insurance (GHI) introduced in 2008 for establishing financially sustainable social security system for the entire population. The Green Card scheme joins the Social Security Institution in 2012. Then the newly established Social Security Institution undertook the management of the Green Card scheme. Government financing of non-contributory health insurance for the poorest deciles and increased coverage of contributory health insurance by richer deciles enabled expansion of the Green Card scheme and the introduction of a unified GHI scheme. Green Card holders have been mandated to apply to an "income test" for GHI. Since 2012, "income test" has been implemented to subject how much premiums are required to healthcare payment for uninsured people. In Turkey, for financing of expenditures in health care is provided different ways. These are the state budget via taxes for preventive care, for the poor and 
Manavgat, G. \& F. Saygılı \& M. Audibert (2020), "Examining the Economic Burden of Out-of-Pocket Health Expenditures for Households in Different Socio-Economic Groups in Turkey”, Sosyoekonomi, Vol. 28(46), 25-49.

those under 18 years old whose parents are uninsured, social security contributions for GHI beneficiaries, private health insurance and out of pocket health expenditures.

In parallel after 2003, healthcare regulations related to delivery, access and finance of health services have accelerated with the "Health Transformation Program" (HTP) in Turkey. Priority policy objectives of this program have been set for effectiveness, efficiency, and equity in the organization, delivery, and financing of health services. The effective increase of government expenditure on healthcare, the increasing of the population included in universal health insurance and the expansion of the risk pool have been an important area of discussion for the purpose of reducing the financial burden of households in out of pocket health expenditures. First in 2005, the transfer of all health facilities attached to the Social Insurance Organization (SIO) to the Ministry of Health $(\mathrm{MoH})$ was a radical change as hospitals managed by MoH were limited.

Actually, health services are provided by the MoH, the Ministry of Defence, the universities and the private sector. The $\mathrm{MoH}$ is the main provider with healthcare delivered in primary, secondary and tertiary health facilities. The private sector has grown notably, despite the fact that healthcare provided in this sector is not covered by public insurance and that the population within the scope of social security had to make a supplementary payment. In 2011, the MoH was given the roles of planning and regulating through Decree-Law No. 663 , which was issued for the purpose of regulating the tasks, authorities and responsibilities of the $\mathrm{MoH}$ and its facilities (Ozgen et al., 2015).

In recent years, there are significant increases in access of healthcare services with health reforms. For example, while per capita hospital visits were 3.1 in 2002, in 2014 it reached $8.4(\mathrm{MoH}, 2015)$. Hence, the ease of access to health services has increased the use of healthcare services, but it has also increased health spending. In the last 14 years, total health expenditures (government and private) have increased by almost four and at higher trend than GDP increase. In parallel health expenditures per capita has increased, and more specifically, OOP doubled. However, with the application of co-payment implemented in 2008 , individuals reduce their demand for health services, allowing a decrease in the OOP growth rate (Table 1). All that provided a reason for the implementation of policies aimed at contributing to private health financing as much as the contribution of the state budget to financing for health services.

Table: 1

\section{GDP and Health Expenditures in Turkey by Years}

\begin{tabular}{|c|c|c|c|c|c|c|c|c|}
\hline & 2002 & 2004 & 2006 & 2008 & 2010 & 2012 & 2014 & 2016 \\
\hline GDP (in million US\$) & 238.425 & 404.786 & 552.468 & 764.335 & 731.61 & 873.982 & 934.185 & 863.721 \\
\hline Total health Expenditures (in million US\$) & 12.05 & 19.98 & 28.42 & 40.84 & 39.03 & 39.00 & 76.42 & 36.63 \\
\hline Current health expenditures in GDP (\%) & 5.1 & 4.9 & 5.1 & 5.2 & 5.0 & 4.4 & 4.3 & 4.2 \\
\hline GDP growth rate (\%) & 6.4 & 9.6 & 7.1 & 0.8 & 8.4 & 4.7 & 5.1 & 3.1 \\
\hline Health expenditures growth rate (\%) & 5.1 & 23.6 & 24.6 & 13.4 & 6.5 & 8.1 & 12.2 & \\
\hline Current Health expenditures per capita, $P P P(U S \$)$ & 475 & 538 & 706 & 844 & 881 & 924 & 1044 & 1089 \\
\hline OOP health expenditure per capita, PPP ((US\$) & 96 & 108 & 167 & 161 & 148 & 147 & 185 & 180 \\
\hline OOP health expenditure growth rate (\%) & 12.7 & 10.5 & 54.6 & -3.1 & -8.5 & -0.06 & 25.8 & -2.7 \\
\hline
\end{tabular}

Source: World Bank Health Expenditures Stat and TurkStat. 
Figure 1 shows an increase in the share of government health expenditures in total expenditures. The share of OOP in private health expenditures, after increasing between 2002 and 2006, remained about $17 \%$ after 2006. The decline of other private health insurance expenditures can be interpreted that households are less likely to need private health insurance coverage due to health insurance regulations and as some disappeared.

Figure: 1

\section{Distribution of Health Expenditures by Financing Source}

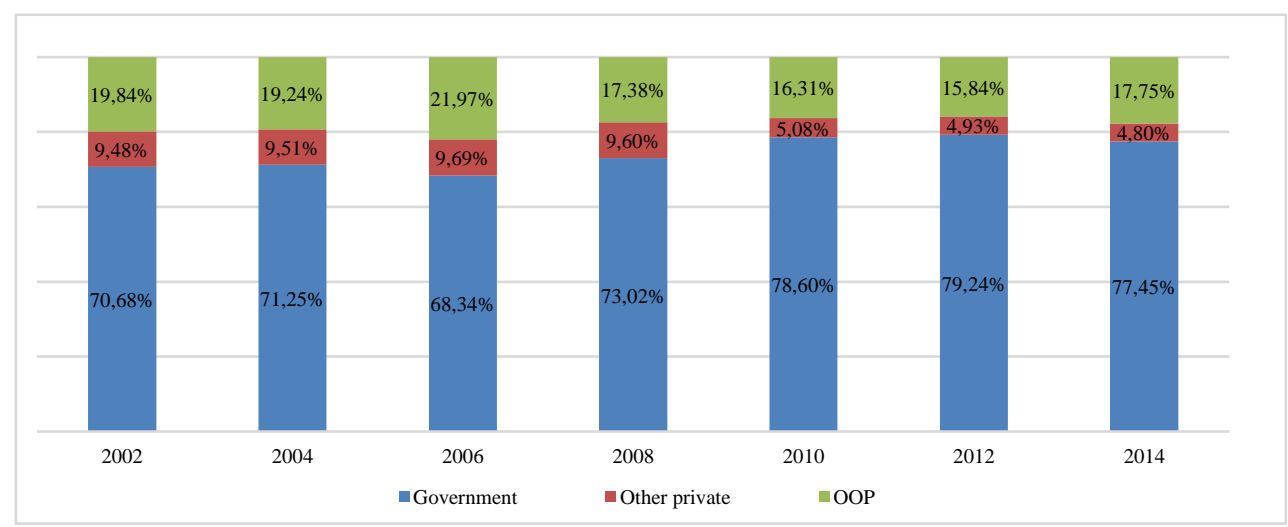

Source: TurkStat Health Expenditures Statistics (2016).

Moreover, health expenditure prevention policies have come to the fore to control of the increasing expenditures. Polices have been implemented which focused on private OOP to control of increased government health expenditures. The policy of restricting health expenditures, arranging for unnecessary healthcare use for moral hazard, and implementing additional incomes for health expenditures has significantly influenced OOP. In 2008, copayment implications were initiated for outpatient and dental examinations which is serviced by the Ministry of Health. On the other hand, some of the services received from private hospitals contracted with SSI for health service have started to be covered by SSI. Thus, the high-income groups who can afford this healthcare services payment have may directed to private healthcare facilities and their out-of-pocket expenditures have increased.

\section{Data and Method}

\subsection{Dataset}

The data used in the study were provided from "Household Budget Survey" (HBS), which was done by TURKSTAT and was represented at national level. Turkish HBSs are consistent with Eurostat's HBS. HBS has been regularly published every year since 2002. Data were collected monthly in the rural and urban areas between January 1st and December 31 st. For our analysis, we kept data every two years between 2002 and 2014. The monthly (annually) number of interviewed households varied between 712 (8544) and 843 (10122) depending of the year (Table 2) 
Manavgat, G. \& F. Saygılı \& M. Audibert (2020), "Examining the Economic Burden of Out-of-Pocket Health Expenditures for Households in Different Socio-Economic Groups in Turkey", Sosyoekonomi, Vol. 28(46), 25-49.

Table: 2

The Number of Participation in HBSs By Years

\begin{tabular}{|c|c|c|}
\hline Years & Monthly & Annually \\
\hline 2002 & 796 & 9555 \\
\hline 2004 & 712 & 8544 \\
\hline 2006 & 714 & 8558 \\
\hline 2008 & 712 & 8549 \\
\hline 2010 & 840 & 10082 \\
\hline 2012 & 832 & 9987 \\
\hline 2014 & 843 & 10122 \\
\hline
\end{tabular}

Source: HBSs 2002-2016.

Three main groups of variables were collected in HBSs : 1) variables that relating to household assets and characteristics (e.g. type of dwelling and ownership, house facilities, ownership of durables and transportation vehicles, household size and settlement etc.); 2) variables that relating to expenditure on consumption (e.g. food, clothing, health and transportation expenditures etc.); 3) variables relating to individuals characteristics (e.g. age, gender and education, employment statue, income occupation, profession and income from main economic activity etc.). In other words, HBSs include household and individuals' characteristics and household expenditures. All goods and services expenditures made by households in the monthly survey are based on the Classification of Individual Consumption by Purpose (COICOP) classification system used by EuroStat. The COICOP classification consists of 12 expenditures groups, including health expenditures. These last expenditures concern household's out-of-pocket (OOP) expenditure for hospital services, medical and pharmacy products, treatment equipment, dental services, laboratory and x-ray services etc. However, insurance premiums are not included in the health expenditures of households.

\subsection{Determination of Catastrophic Health Expenditure}

Catastrophic health spending is defined as an out-of-pocket (OOP) expenditures which lead to waive basic needs of households, to borrow by selling their assets or to impoverish them (Berki, 1986; Wagstaff \& van Doorslaer, 2003). In other words, catastrophic health expenditures are OOP that exceed a certain percentage (threshold) of household's expenditures or ability (capacity) to pay. However, there is no consensus about what exactly the denominator and threshold values used to determine the catastrophic effects of OOP health spending.

Firstly, in this study, the financial burden of OOP health expenditures is calculated by taking into account the "capacity to pay" approach accepted by World Health Organization (WHO) within the framework of fair financing (Xu et al., 2005). In many studies, it is often already seen that this method is followed (Minh et al., 2013; Y1ldirım et al., 2010; Su et al., 2006; Arsenijevic et al., 2013; Kim \& Yang, 2011; Gotsadze et al., 2009; Somkotra \& Lagrada, 2009; Lee et al., 2016). The capacity to pay (CTP) is defined as the remaining expenditure after meeting basic living needs so it is non-subsistence expenditures. The subsistence expenditures are determined as food expenditures. OOPs are defined as catastrophic health expenditure which exceeds $40 \%$ of capacity to pay (Xu et al., 2003, 2005). We used $40 \%$ of the capacity to pay as the reference threshold value, and tested other 
Manavgat, G. \& F. Sayg1l \& M. Audibert (2020), "Examining the Economic Burden of Out-of-Pocket Health Expenditures for Households in Different Socio-Economic Groups in Turkey", Sosyoekonomi, Vol. 28(46), 25-49.

thresholds such as $10 \%, 20 \%$ and $30 \%$. Thus, attention is drawn to how the path of catastrophic health expenditures differs for different fixed thresholds values by year. In addition, we used alternative thresholds, because using only one cut-point value or threshold is inevitably arbitrary and may result in inaccuracy and misinterpretation.

The main difference of our study from other previous studies is that the variable threshold for different socioeconomic groups was taken into account in determining catastrophic health expenditure. In other words, previous analyses were made based on the assumption that the threshold is fixed whatever socioeconomic groups but arguing that different thresholds lead to different conclusions about the economic impact of household health expenditure (Goudge et al., 2009).

However, if the fixed threshold is used for all socioeconomic groups, for example $10 \%$, it is very difficult to interpret. For example, a household which has 100 dollars and spends 10 dollars, and a household which has 1000 dollars and spends 100 dollars, are clearly faced with a very different life. The balance of the remaining rich households 900 dollars is 10 times more than pre-expenditure income for poor households, in which case both are thought to have been catastrophic. It should be assumed that the value after the expenditures or income is different for the rich and poor households. An alternative framing of the problem is that assuming diminishing marginal utility of money, beyond a fixed threshold level, the marginal utility of the next dollar is much higher for the poor households. Because the absolute amount left after the threshold level is exceeded, and its utility differs for different absolute levels of capacity to pay. It can be more appropriate to consider catastrophe at different levels for different socioeconomic groups. This hypothesis is compatible with the vertical equity principle, which would mean that higher expenditure proportions would be required to designate a richer household as having incurred catastrophe or vice-versa (Onoka et al., 2011).

In addition, we used variable threshold approach suggested by Onoka et al., (2011). Catastrophic health expenditure was examined based on uniform threshold levels of nonfood expenditure and a novel set of variable thresholds in which the levels for various socioeconomic groups were weighted by the ratio of household expenditure on food. The food expenditures have been considered for determining variable thresholds and it is assumed to be sensitive enough to capture the differences in funding and spending among the different socioeconomic groups. In addition, while households' income increase, the share of food expenditure decreases even if the total expenditure increases. Therefore, food expenditures have been used as a weight to determine the catastrophic expenditures thresholds.

Variable thresholds were based on the ratio of food expenditure level between an 'index' quintile and the remaining quintiles. First, indexed thresholds were established for the relative share of food expenditure in the poorest (Q1) households. In this scenario, it indexed the thresholds to the poorest quintile (Q1). The threshold assumed for catastrophic health expenditure is $10 \%$ (th $=10 \%$ ) for this group. Analogously for richest group (Q5), an 
Manavgat, G. \& F. Saygılı \& M. Audibert (2020), "Examining the Economic Burden of Out-of-Pocket Health Expenditures for Households in Different Socio-Economic Groups in Turkey", Sosyoekonomi, Vol. 28(46), 25-49.

alternative procedure was followed. The threshold assumed for catastrophic health expenditure is $40 \%$ (th $=40 \%$ ) for this group. For all procedures, equation 1 was employed:

$$
\mathrm{V}_{\mathrm{i}}=\text { th } \mathrm{x} \text { Foodexp } / \text { Foodexpn }
$$

where;

$\mathbf{V}_{\mathbf{i}}=$ the threshold used for the $i$ th quintile (equivalent household expenditure quintile)

th: threshold (if indexed for the poorest (Q1), it is 10\% or indexed for richest (Q5), it is $40 \%$ )

Foodexpi : food expenditure in the ith quintile

Foodexpn : food expenditure in the index quintile (poorest (Q1) or richest (Q5) )

Thus, for calculating for catastrophic health expenditure, "capacity to pay" value was used as a denominator for each household, like the method used at the fixed threshold. Other word, out-of-pocket health expenditures were divided by the capacity to pay -method by $\mathrm{Xu}$, K. (2005)-. If this value exceeds the determined variable threshold for each quintile, we call that this household incurs catastrophic health expenditure.

Firstly, for all procedure, relative food expenditures were calculated for each quintile and then used as the weight for selected thresholds. Monthly average food expenditures were calculated based on equivalent household expenditure quintile in Table 3. OECD equivalent household size ${ }^{3}$ was used. The average monthly food expenditure of poorest households was 108.4 $\mathrm{TL}^{4}$ and richest households were $218.6 \mathrm{TL}$ in 2002. According to this, the average monthly food expenditure in the richest group is about 2 times higher than those in the poorest group. In 2016, the average monthly food expenditure of poorest and richest was 452.6TL and 909.7 TL respectively. In other words, food expenditures in total expenditures is always high in poor groups relatively. The gap increases slightly some years. The share of food expenditures is also shown in Table 3. Although the share of food expenditures in total expenditures for poorest and richest groups did not show a significant change over the years, the average share of food expenditure is 0.37 and 0.15 respectively. This is consistent with the Engel law (Engel, 1857; Aykaç, 2018).

3 OECD equivalent household size: The household size is calculated for the first adult weight at 1,14 years and older at 0.5 , less than 14 years old at 0.3. Other means, formula (B0.56) is used to estimate the equivalence scale, where $\beta$ is the household size.

$4 T L=$ Turkish Lira. 
Table: 3

Monthly Average Food Expenditure by Socioeconomics Group and Share of Food Expenditures in Total Expenditures

\begin{tabular}{|c|c|c|c|c|c|}
\hline Food Expenditures (TL)* & $\boldsymbol{Q 1}$ & $\boldsymbol{Q 2}$ & $\boldsymbol{Q 3}$ & $\boldsymbol{Q 4}$ & $\boldsymbol{Q 5}$ \\
\hline 2002 & $108.4(0.41)$ & $135.1(0.35)$ & $156.3(0.33)$ & $174.3(0.26)$ & $218.6(0.16)$ \\
\hline 2004 & $171.9(0.47)$ & $203.8(0.37)$ & $235.2(0.32)$ & $279.1(0.29)$ & $362.9(0.20)$ \\
\hline 2006 & $179.3(0.39)$ & $235.0(0.32)$ & $263.6(0.25)$ & $312.0(0.25)$ & $388.9(0.17)$ \\
\hline 2008 & $247.7(0.38)$ & $311.6(0.30)$ & $358.7(0.26)$ & $404.8(0.23)$ & $503.6(0.16)$ \\
\hline 2010 & $231.6(0.31)$ & $302.9(0.26)$ & $334.1(0.23)$ & $392.2(0.20)$ & $442.6(0.12)$ \\
\hline 2012 & $306.3(0.32)$ & $394.0(0.26)$ & $461.4(0.23)$ & $540.0(0.21)$ & $660.7(0.13)$ \\
\hline 2014 & $383.9(0.32)$ & $468.5(0.27)$ & $557.5(0.24)$ & $671.4(0.22)$ & $804.9(0.14)$ \\
\hline 2016 & $452.6(0.40)$ & $578.9(0.28)$ & $655.4(0.25)$ & $769.1(0.22)$ & $909.7(0.13)$ \\
\hline
\end{tabular}

Source: Calculated based on HBS (2002-2016) by authors.

* Monthly expenditures based 2003 real prices, TL: Turkish Lira, () Food expenditures in total expenditures.

Relative average food expenditures ratios are calculated by year for the different groups (Tables $4 \mathrm{a}$ and $4 \mathrm{~b}$ ). They were used as a weighting for different socioeconomic groups in order to compare the prevalence of catastrophic expenditures between socioeconomic groups. For example, when the threshold of catastrophic health expenditure is defined as exceeds $10 \%$ of capacity to pay for poor, the threshold for the richest group should be determined as $21.1 \%$ in 2004 (Table 4a). On the other hand, if the threshold catastrophic health expenditures are defined as $40 \%$ of the capacity to pay, it is seen that the threshold calculated according to the relative food expenditure share of those in the richest quintile should be chosen as $18.8 \%$ for the poorest group in 2004. Similarly, it has been shown what the threshold values might be for different socio-economic groups and different year (Table 4b). Thus, it is seen that the lowest threshold value of $10 \%$ for the variable threshold values is increased to about $20 \%$ for the rich groups. If the highest threshold value of $40 \%$ is taken into account for the variable threshold value, threshold value for poor groups should be set to about $18 \%$ - albeit varying with years.

\section{Table: $4 \mathbf{a}$}

\section{Household Relative Food Expenditure and Variable Thresholds Indexed the Poorest}

\begin{tabular}{|c|c|c|c|c|c|c|c|c|c|c|c|}
\hline $\mathrm{p}=\mathrm{Qi} / \mathrm{Q} 1$ & Q1 & Q2 & Q3 & Q4 & Q5 & Variable Thresholds Ref. (\% 10) & Q1 & Q2 & Q3 & Q4 & Q5 \\
\hline 2002 & 1.00 & 1.24 & 1.44 & 1.60 & 2.01 & 2002 & 10.0 & 12.4 & 14.4 & 16.0 & 20.1 \\
\hline 2004 & 1.00 & 1.18 & 1.36 & 1.62 & 2.11 & 2004 & 10.0 & 11.8 & 13.6 & 16.2 & 21.1 \\
\hline 2006 & 1.00 & 1.31 & 1.47 & 1.74 & 2.16 & 2006 & 10.0 & 13.1 & 14.7 & 17.4 & 21.6 \\
\hline 2008 & 1.00 & 1.25 & 1.44 & 1.63 & 2.03 & 2008 & 10.0 & 12.5 & 14.4 & 16.3 & 20.3 \\
\hline 2010 & 1.00 & 1.30 & 1.44 & 1.69 & 1.91 & 2010 & 10.0 & 13.0 & 14.4 & 16.9 & 19.1 \\
\hline 2012 & 1.00 & 1.28 & 1.50 & 1.76 & 2.15 & 2012 & 10.0 & 12.8 & 15.0 & 17.6 & 21.5 \\
\hline 2014 & 1.00 & 1.22 & 1.45 & 1.74 & 2.09 & 2014 & 10.0 & 12.2 & 14.5 & 17.4 & 20.9 \\
\hline 2016 & 1.00 & 1.27 & 1.44 & 1.70 & 2.00 & 2016 & 10.0 & 12.7 & 14.4 & 17.0 & 20.0 \\
\hline
\end{tabular}

Table: $4 \mathrm{~b}$

Household Relative Food Expenditure and Variable Thresholds Indexed the Richest

\begin{tabular}{|c|c|c|c|c|c|c|c|c|c|c|c|}
\hline$r=Q i / Q 5$ & $Q 1$ & $Q 2$ & Q3 & $Q 4$ & Q5 & Variable Thresholds Ref. (\%40) & $Q 1$ & $Q 2$ & $Q 3$ & $Q 4$ & Q5 \\
\hline 2002 & 0.49 & 0.61 & 0.71 & 0.79 & 1.00 & 2002 & 19.6 & 24.4 & 28.4 & 31.6 & 40.0 \\
\hline 2004 & 0.47 & 0.56 & 0.64 & 0.76 & 1.00 & 2004 & 18.8 & 22.4 & 25.6 & 30.4 & 40.0 \\
\hline 2006 & 0.46 & 0.60 & 0.67 & 0.80 & 1.00 & 2006 & 18.4 & 24.0 & 26.8 & 32.0 & 40.0 \\
\hline 2008 & 0.49 & 0.61 & 0.71 & 0.80 & 1.00 & 2008 & 19.6 & 24.4 & 28.4 & 32.0 & 40.0 \\
\hline 2010 & 0.52 & 0.68 & 0.75 & 0.88 & 1.00 & 2010 & 20.8 & 27.2 & 30.0 & 34.2 & 40.0 \\
\hline 2012 & 0.46 & 0.59 & 0.69 & 0.81 & 1.00 & 2012 & 18.4 & 23.6 & 27.6 & 32.4 & 40.0 \\
\hline 2014 & 0.47 & 0.58 & 0.69 & 0.83 & 1.00 & 2014 & 18.8 & 23.2 & 27.6 & 33.2 & 40.0 \\
\hline 2016 & 0.49 & 0.36 & 0.72 & 0.84 & 1.00 & 2016 & 19.6 & 14.4 & 28.8 & 33.6 & 40.0 \\
\hline
\end{tabular}


Manavgat, G. \& F. Saygılı \& M. Audibert (2020), "Examining the Economic Burden of Out-of-Pocket Health Expenditures for Households in Different Socio-Economic Groups in Turkey”, Sosyoekonomi, Vol. 28(46), 25-49.

In addition, the determinants of catastrophic payments were examined with binary logistic regression, using pooled analysis of 2002-2016 data. Regression analysis was done for each threshold calculation method that used to define catastrophic health expenditures, different fixed thresholds and variable threshold values. The explanatory variables used in the models were determined based on previous national and international studies and availability of appropriate data in HBS-TurkStat. The dependent and independent variables used in the study are presented in Table 5.

Table: 5

Variables Used in Regression Models

\begin{tabular}{|c|c|}
\hline Dependent Variables & Definition \\
\hline Cata (Exceed threshold levels) & $\begin{array}{l}\text { Household total OOP healthcare expenditures share exceed any Fixed threshold of their capacity to pay (\% } \% \text {, } \\
\% 30, \% 20 \text { and } \% 10 \text { ) or Variable thresholds, if Yes }=1 \text { Otherwise }=0\end{array}$ \\
\hline Independent Variables & Definition \\
\hline $\begin{array}{l}\text { Health Insurance Type of HH } \\
\text { Head }\end{array}$ & Household head insurance type, if Non-insurance $=4$ Green Card $=3$ Private $=2$ and Public Insurance $5=1$ \\
\hline Gender of HH head & Household head gender, if Female $=1$ or Male $=0$ \\
\hline Education Level of $\mathrm{HH}$ head & Household head education level, if Primary or less $=1$ Secondary $=2$ Tertiary or high $=3$ \\
\hline Disability of HH head & Mental and/or physical disability of HH head for working, if Yes $=1$ Otherwise $=0$ \\
\hline $\begin{array}{l}\text { Employment Status in The Main } \\
\text { Job of HH Head }\end{array}$ & $\begin{array}{l}\text { Unemployed=0, Regular employee }=1 \text {, Casual employee }=2, \text { Employer=3, Self-employed }=4 \text {, Unpaid family } \\
\text { worker }=5\end{array}$ \\
\hline Having Preschool Aged Child & Household having under 5 age chid, if Yes $=1$ Otherwise $=0$ \\
\hline Having Elderly Member & Household having elderly member above 65 age, if Yes $=1$ Otherwise $=0$ \\
\hline Household Size & Number of Household (continuous variable) \\
\hline Settlement & Location of the residence, if Rural $=1$ Urban $=0$ \\
\hline Expenditures Quintiles & Poorest $=1$ in reference $2^{\text {nd }}$ Quintile $=23^{\text {rd }}$ Quintile $=34^{\text {th }}$ Quintile $=4$ Richest $=5$ \\
\hline Year & Survey year where 2002 is the omitted category \\
\hline
\end{tabular}

\section{Results}

Table 6 present the descriptive characteristics of the households. It is noteworthy that the ratio of non-insured households decreased over the period from $23.1 \%$ in 2002 to $4.7 \%$ in 2016. The proportion of households with Green Card has significant increases until 2010 but has not changed much after that. Nearly for all of the years, about one-third of households have children under 5 years old and one-five elderly persons in the household. One-third of households live in rural settlements. Approximately one- ten household heads have an education at the level of higher education, but in recent, the increase in the proportion of those who have higher education is striking. On the other hand, in majority of sample, household heads are employed, male and non-disabled.

The average monthly household consumption expenditure, food expenditure and capacity to pay increased by 58\%, 33\% and 61\%, from 2002 to 2016 respectively. In parallel with the average consumption expenditure, the capacity to pay also increased as the average OOP health expenditures increased by $75 \%$. Another interesting point is that the percentage of households who are faced with any OOP is increased. While $46.4 \%$ of the households are

5 Before 2006, it included three schemes (GERF, SIO and Bağ-Kur), SSI was established to unify all this insurance schemes in 2006. For integrity, we prefer to call this scheme as Public Insurance for all years. 
faced any OOP health expenditure in 2002, it increased almost every year and reached to $59.2 \%$ in 2016.

Table: 6

Descriptives of Household Characteristics by Year

\begin{tabular}{|c|c|c|c|c|c|c|c|c|}
\hline Household Monthly Expenditure Features $(T L)^{*}$ & $\underline{2002}$ & 2004 & $\underline{2006}$ & 2008 & 2010 & 2012 & 2014 & $\underline{2016}$ \\
\hline Average Total Consumption Expenditure & $\overline{718}$ & $\overline{794}$ & $\overline{878}$ & $\overline{1002}$ & $\overline{969}$ & 1137 & $\overline{1140}$ & $\overline{1141}$ \\
\hline Average Non-Food Consumption Expenditure & 560 & 564 & 665 & 766 & 778 & 908 & 902 & 980 \\
\hline Average Food Consumption Expenditure & 178 & 230 & 213 & 236 & 191 & 229 & 238 & 240 \\
\hline Average Capacity to Pay & 592 & 613 & 716 & 811 & 813 & 963 & 958 & 967 \\
\hline Proportion of Households Incurred any OOP (\%) & 46.4 & 45.6 & 54.5 & 54.1 & 63.8 & 63.6 & 66.3 & 59.2 \\
\hline Average OOP Health Expenditure & 13.8 & 17.3 & 18.4 & 18.0 & 22.4 & 20.8 & 24.0 & 22.5 \\
\hline Average OOP Health Expenditure in Non-Zero Households & 27.6 & 38.0 & 33.7 & 33.1 & 34.3 & 32.7 & 36.1 & 37.9 \\
\hline Household Variables (\%) & 2002 & 2004 & 2006 & 2008 & 2010 & 2012 & 2014 & 2016 \\
\hline \multicolumn{9}{|l|}{ Health insurance type of Household head } \\
\hline Public Insurance & 68.2 & 67.9 & 73.3 & 79.0 & 77.9 & 83.9 & 84.3 & 83.7 \\
\hline Private & 5.1 & 4.9 & 0.8 & 1.2 & 1.4 & 2.2 & 0.9 & 0.03 \\
\hline Green Card & 3.5 & 5.2 & 10.2 & 10.7 & 10.6 & 7.9 & 9.1 & 11.3 \\
\hline Non-insured & 23.1 & 21.9 & 15.6 & 8.8 & 9.9 & 5.9 & 5.4 & 4.7 \\
\hline \multicolumn{9}{|l|}{ Education level of $\mathrm{HH}$ head } \\
\hline Primary or less & 74.7 & 72.7 & 73.8 & 69.8 & 71.2 & 67.1 & 68.1 & 67.6 \\
\hline Secondary & 16.2 & 17.7 & 17.4 & 18.2 & 16.1 & 17.6 & 16.2 & 16.4 \\
\hline Tertiary or high & 9.1 & 9.5 & 8.7 & 11.9 & 12.6 & 15.1 & 15.6 & 15.8 \\
\hline Gender of HH head - Male- & 89.9 & 89.4 & 89.6 & 88.7 & 86.2 & 86.7 & 86.4 & 86.7 \\
\hline Disability of HH head & 10.2 & 6.9 & 8.5 & 5.1 & 6.3 & 7.3 & 7.6 & 7.9 \\
\hline \multicolumn{9}{|l|}{$\begin{array}{l}\text { Employment Status in The Main Job of HH Head } \\
\text { Employed }\end{array}$} \\
\hline Regular employee & 38.9 & 34.2 & 36.5 & 36.6 & 34.8 & 37.4 & 38.3 & 38.1 \\
\hline Casual employee & 6.6 & 6.8 & 5.9 & 5.9 & 5.6 & 6.2 & 5.9 & 4.9 \\
\hline Employer & 5.7 & 4.6 & 4.9 & 5.2 & 4.0 & 4.2 & 3.9 & 3.5 \\
\hline Self-employed & 18.8 & 22.5 & 22.7 & 20.3 & 21.1 & 20.4 & 20.2 & 20.4 \\
\hline Unpaid family worker & 0.2 & 1.3 & 0.2 & 0.2 & 1.1 & 0.4 & 0.5 & 0.2 \\
\hline Unemployed & 29.7 & 30.5 & 30.0 & 31.8 & 33.2 & 31.2 & 30.9 & 32.3 \\
\hline Average $\mathrm{HH}$ size & 4.3 & 4.1 & 4.0 & 3.8 & 3.8 & 3.7 & 3.6 & 3.5 \\
\hline Having Elderly Member (65+ years old ) & 17.3 & 18.5 & 19.5 & 20.3 & 20.6 & 21.6 & 23.5 & 23.7 \\
\hline Having Preschool Aged Child (under 5 years old) & 34.5 & 31.1 & 31.5 & 30.6 & 27.1 & 25.0 & 25.6 & 26.1 \\
\hline Number of Observation $(\mathrm{N})$ & 9555 & 8544 & 8558 & 8549 & 10082 & 9987 & 10122 & 12096 \\
\hline
\end{tabular}

* Monthly expenditures based 2003 real prices.

On the other hand, this increase in the percentage of households with OOP may be attributable to the increase in household's use of healthcare services. As health services become more widespread and cost more affordable, the proportion of households faced any health expenditures may also have increased.

On the other side, taking into account only the households with non-zero OOP health spending, the average value of OOP health expenditures has increased by $30 \%$. The share of OOP in total consumption expenditure (exp) and capacity to pay (ctp) are shown in Figure 2. In addition, when looking at results among households with non-zero OOP, we see that the share of health payments in total expenditure and capacity to pay is higher.

Undoubtedly, the share of OOP should be expected to vary among different economic groups. In Table 7, OOP payments for healthcare are calculated as a percentage of total household expenditure based on quintile groups of equivalent household expenditure. In the poorest quintile (Q1), the share of OOP in total expenditures increased by about $38 \%$ in 2016 compared to 2002, while in the richest group (Q5) it decreased by about $10 \%$. Considering the share of in capacity to pay, the proportion of OOP in poor quintile is closer to the richest quintile and exceeds its in 2014. Over the period, the share of OOP in capacity to pay 
increased by $29 \%$ in the poorest group but decreased by about $13 \%$ in the richest group. This may indicate that the economic burden of OOP may be increased in poor groups. The result of the analysis of variance (ANOVA) made by pooling of the share OOP in total expenditures and capacity to pay during 2002-2016. It shows that there are statistically significant differences between household expenditure quintiles.

Figure: 2

Mean OOP Payments for Healthcare and Its Share in Total Expenditure and Capacity to Pay by Year (\%)

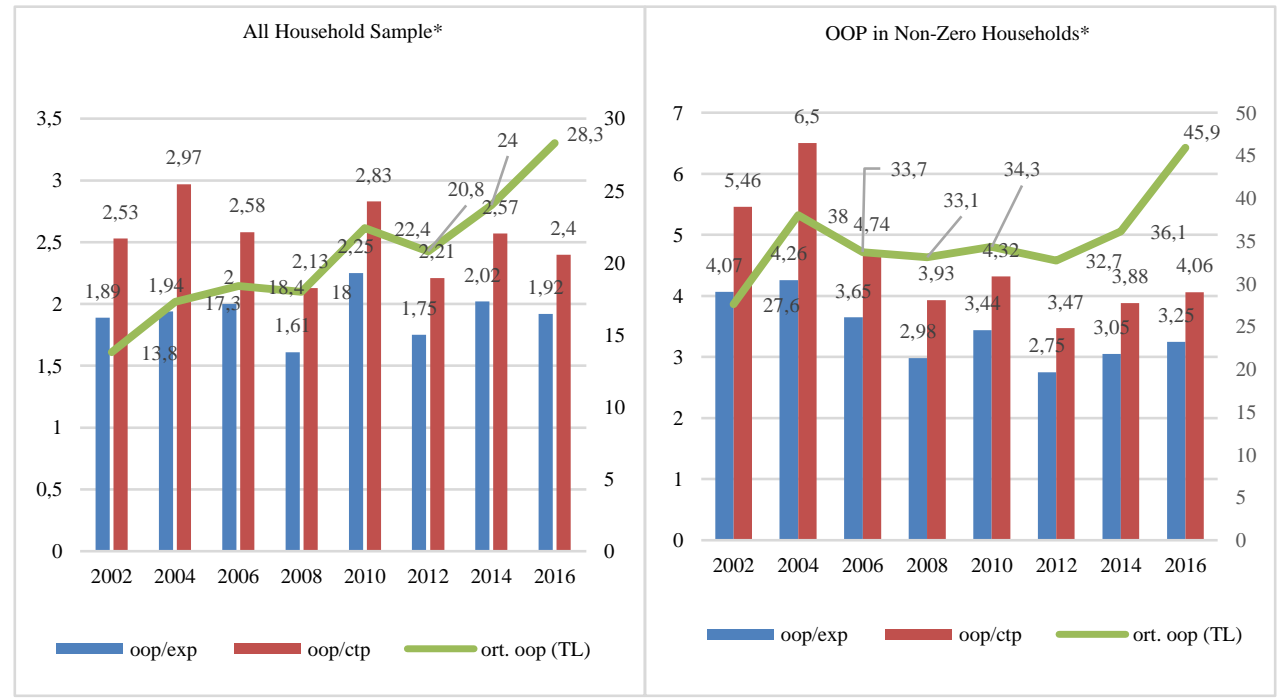

* The secondary vertical axis is shown as TL.

Table: 7

OOP Health Expenditures Share of Households in CTP And Expenditures by Quintile Groups of Equivalent Household Expenditure (\%)

\begin{tabular}{|c|c|c|c|c|c|c|c|c|c|c|}
\hline & \multicolumn{2}{|c|}{$Q 1$} & \multicolumn{2}{|c|}{$Q 2$} & \multicolumn{2}{|c|}{$Q 3$} & \multicolumn{2}{|c|}{$Q 4$} & \multicolumn{2}{|c|}{ Q5 } \\
\hline Years & oop/exp & oop/ctp & oop/exp & oop/ctp & oop/exp & oop/ctp & oop/exp & oop/ctp & oop/exp & oop/ctp \\
\hline 2002 & 1.37 & 2.26 & 1.87 & 2.32 & 2.11 & 2.89 & 1.78 & 2.24 & 2.61 & 2.95 \\
\hline 2004 & 1.03 & 3.03 & 1.87 & 3.29 & 1.89 & 2.81 & 1.98 & 2.61 & 1.97 & 3.09 \\
\hline 2006 & 1.72 & 2.66 & 1.70 & 2.37 & 1.74 & 2.26 & 2.21 & 2.69 & 2.59 & 2.93 \\
\hline 2008 & 1.46 & 2.39 & 1.29 & 1.82 & 1.58 & 2.07 & 1.66 & 2.02 & 2.06 & 2.33 \\
\hline 2010 & 2.00 & 3.02 & 1.62 & 2.17 & 2.12 & 2.64 & 2.58 & 3.05 & 2.93 & 3.24 \\
\hline 2012 & 1.70 & 2.52 & 1.55 & 2.06 & 1.64 & 2.05 & 1.83 & 2.17 & 2.04 & 2.24 \\
\hline 2014 & 1.93 & 2.92 & 1.72 & 2.33 & 1.94 & 2.45 & 2.18 & 2.59 & 2.33 & 2.57 \\
\hline 2016 & 1.82 & 2.68 & 1.62 & 2.17 & 1.71 & 2.14 & 2.02 & 2.37 & 2.44 & 2.66 \\
\hline \multicolumn{5}{|c|}{ Anova Test } & \multicolumn{2}{|c|}{$\frac{1}{S S .(d f)}$} & \multicolumn{2}{|c|}{$F$} & \multicolumn{2}{|c|}{ Prob $>F$} \\
\hline \multicolumn{5}{|c|}{ Between grups- oop/exp } & \multicolumn{2}{|c|}{$0.291(4)$} & \multicolumn{2}{|c|}{33.43} & \multicolumn{2}{|c|}{0.0000} \\
\hline \multicolumn{5}{|c|}{ Between grups- oop/ctp } & \multicolumn{2}{|c|}{0.0790} & \multicolumn{2}{|c|}{4.94} & \multicolumn{2}{|c|}{0.0006} \\
\hline
\end{tabular}

The share of out-of-pocket health expenditures according the health insurance scheme was calculated in Table 8. The OOP health expenditures share of households increased in public insurance scheme. This share in capacity to pay fluctuated from 2002 to 
2016 but increased by about $13 \%$. On the other hand, this share for households among Green Card holders decreased by about $9 \%$. It is also noteworthy that since 2010 , there has been a significant increase in the share of OOP health spending between Public Insurance -SSIowners and Green Card holders.

\section{Table: 8}

\section{OOP Health Expenditure Shares of Households in CTP and Expenditures Across the Health Insurance Schemes (\%)}

\begin{tabular}{|c|c|c|c|c|c|c|c|c|}
\hline & \multicolumn{2}{|c|}{ Public Insurance } & \multicolumn{2}{|c|}{ Private } & \multicolumn{2}{|c|}{ Green Card } & \multicolumn{2}{|c|}{ Uninsured } \\
\hline Years & oop/exp & oop/ctp & oop/exp & oop/ctp & oop/exp & oop/ctp & oop/exp & oop/ctp \\
\hline 2002 & 1.79 & 2.31 & 2.11 & 2.91 & 2.29 & 3.49 & 2.06 & 2.94 \\
\hline 2004 & 1.85 & 2.56 & 1.98 & 3.06 & 2.12 & 4.37 & 2.18 & 3.87 \\
\hline 2006 & 1.93 & 2.41 & 1.36 & 2.80 & 2.11 & 3.23 & 2.23 & 3.02 \\
\hline 2008 & 1.54 & 1.96 & 2.37 & 2.95 & 1.63 & 2.63 & 2.08 & 2.85 \\
\hline 2010 & 2.24 & 2.74 & 2.89 & 3.79 & 2.42 & 3.44 & 2.02 & 2.71 \\
\hline 2012 & 1.75 & 2.15 & 1.58 & 2.03 & 1.78 & 2.67 & 1.80 & 2.51 \\
\hline 2014 & 2.00 & 2.50 & 1.99 & 2.55 & 2.04 & 3.06 & 2.26 & 2.95 \\
\hline 2016 & 2.14 & 3.07 & 2.05 & 2.10 & 1.98 & 2.37 & 2.36 & 2.85 \\
\hline \multicolumn{4}{|c|}{ Anova Test } & \multicolumn{2}{|c|}{$S S .(d f)$} & \multicolumn{2}{|c|}{$F$} & Prob $>F$ \\
\hline \multicolumn{4}{|c|}{ Between grups- oop/exp } & \multicolumn{2}{|c|}{$0.0523(3)$} & \multicolumn{2}{|c|}{8.00} & 0.000 \\
\hline \multicolumn{4}{|c|}{ Between grups- oop/ctp } & \multicolumn{2}{|c|}{$0.5764(3)$} & \multicolumn{2}{|c|}{48.20} & 0.000 \\
\hline
\end{tabular}

Firstly, the proportion of household incurred catastrophic health expenditures for different fixed thresholds are calculated for all households ${ }^{6}$ in Table 9 . The proportion of households who incurred catastrophic health expenditures decreased during HTP, except in 2010 and in 2016 where a slight increase was observed for the thresholds of $10 \%$ and $20 \%$. When the threshold is fixed at $40 \%$, the proportion of households concerned is below $1 \%$ over the whole period. However, there is some increase at this threshold level in 2016. The same path is also shown for the threshold value of 30 .

Table: 9

\section{Prevalence of Catastrophic Health Expenditures for Different Fixed Thresholds by}

$$
\text { Year }(\%)
$$

\begin{tabular}{|c|c|c|c|c|}
\hline Cata Levels (\%) & CATA $\geq 10$ & CATA $\geq 20$ & CATA $\geq 30$ & CATA $\geq 40$ \\
\hline 2002 & 7.62 & 2.98 & 1.36 & 0.63 \\
\hline 2004 & 7.99 & 3.96 & 2.19 & 0.84 \\
\hline 2006 & 7.79 & 2.73 & 0.89 & 0.50 \\
\hline 2008 & 5.32 & 2.07 & 0.97 & 0.41 \\
\hline 2010 & 6.85 & 2.33 & 0.87 & 0.36 \\
\hline 2012 & 5.10 & 1.59 & 0.48 & 0.16 \\
\hline 2014 & 6.24 & 1.88 & 0.75 & 0.31 \\
\hline 2016 & 6.25 & 1.97 & 0.73 & 0.33 \\
\hline
\end{tabular}

The main differences in the study, the proportion of households incurred catastrophic health expenditures are calculated for variable thresholds. Before (Table $4 \mathrm{a}$ and $4 \mathrm{~b}$ ), we calculated variable thresholds for the different socioeconomic groups and each year. Thus, it has been taken into account how the results with fixed thresholds differ from the variable 
threshold method that allows the threshold to change between different socioeconomic groups. According to threshold $10 \%$ indexed to the poorest quintile (Q1) and threshold \%40 indexed to the richest quintile (Q5), the proportion of household incurred catastrophic health expenditures were calculated in Table 10. At the lowest threshold of $10 \%$ that indexed to poorest quintile, while the ratio of households in catastrophic health payments in 2002 was $4.34 \%$, it showed a slight decrease $3.28 \%$ in 2016.

However, at the $10 \%$ fixed threshold, generally proportion of incurring catastrophic health expenditures was higher and also it has decreased less. On the other hand, at the highest threshold of $40 \%$ that indexed to richest quintile, the proportion of households incurred catastrophic health expenditure decreased from $1.70 \%$ to $1.38 \%$ from 2002 to 2016, respectively. The decline in the proportion of household in catastrophic health expenditures is very limited according to fixed threshold (Table 10).

Table: 10

\section{Prevalence of Catastrophic Health Spending for Variable Thresholds by Year (\%)}

\begin{tabular}{|c|c|c|}
\hline \multicolumn{3}{|c|}{ Catastrophic health expenditures at variable thresholds } \\
\hline$\underline{\underline{\text { Years }}}$ & Q1cata $\geq 10$ - Qicata $\geq 10^{*} p$ & Qicata $\geq 40 * \mathrm{r}-05 \mathrm{cata} \geq 40$ \\
\hline & $Q 1_{\text {cata }} \geq 10-Q 5_{\text {cata }} \geq 20.1$ & $Q I_{\text {cata }} \geq 19.6-Q 5_{\text {cata }} \geq 40$ \\
\hline \multirow[t]{2}{*}{2002} & 4.34 & 1.70 \\
\hline & $Q 1_{\text {cata }} \geq 10-Q 5_{\text {cata }} \geq 21.1$ & $Q 1_{\text {cata }} \geq 18.8-Q 5_{\text {cata }} \geq 40$ \\
\hline \multirow[t]{2}{*}{2004} & 5.77 & 3.03 \\
\hline & $Q 1_{\text {cata }} \geq 10-Q 5_{\text {cata }} \geq 21.6$ & $Q 1_{\text {cata }} \geq 18.4-Q 5_{\text {cata }} \geq 40$ \\
\hline \multirow{2}{*}{2006} & 4.62 & 1.50 \\
\hline & $Q 1_{\text {cata }} \geq 10-Q 5_{\text {cata }} \geq 20.3$ & $Q 1_{\text {cata }} \geq 19.6-Q 5_{\text {cata }} \geq 40$ \\
\hline \multirow[t]{2}{*}{2008} & 3.56 & 1.25 \\
\hline & $Q 1_{\text {cata }} \geq 10-Q 5_{\text {cata }} \geq 19.1$ & $Q 1_{\text {cata }} \geq 20.8-Q 5_{\text {cata }} \geq 40$ \\
\hline \multirow[t]{2}{*}{2010} & 4.39 & 1.17 \\
\hline & $Q 1_{\text {cata }} \geq 10-Q 5_{\text {cata }} \geq 21.5$ & $Q 1_{\text {cata }} \geq 18.4-Q 5_{\text {cata }} \geq 40$ \\
\hline \multirow[t]{2}{*}{2012} & 3.13 & 0.80 \\
\hline & $Q 1_{\text {cata }} \geq 10-Q 5_{\text {cata }} \geq 20.9$ & $Q 1_{\text {cata }} \geq 18.8-Q 5_{\text {cata }} \geq 40$ \\
\hline \multirow[t]{2}{*}{2014} & 3.77 & 1.09 \\
\hline & $Q I_{\text {cata }} \geq 10-Q 5_{\text {cata }} \geq 20.1$ & $Q I_{\text {cata }} \geq 19.6-Q 5_{\text {cata }} \geq 40$ \\
\hline 2016 & 3.28 & 1.38 \\
\hline \multicolumn{3}{|c|}{$\begin{array}{l}\mathrm{p} \text { : The ratio of average food expenditure to the poorest (Qi/Q1) } \\
r: \text { The ratio of average food expenditure to the richest (Qi/Q5) }\end{array}$} \\
\hline
\end{tabular}

The point that draws attention in the results obtained at the variable thresholds based on different socioeconomic groups, is that the proportion of household incurred catastrophic health spending at the low variable threshold is lower than the fixed lower threshold and higher at the high variable threshold. So, when the threshold is measured by using indexed food expenditure of the poorest, the low threshold increases towards rich quintile and thus the rate of those who make catastrophic health expenditure is determined more precisely. A similar approach applies to rich-indexed threshold values. In this approach, actually there is no considerable decrease in the financial burden of out-of-pocket health expenditures in Turkey during the HTP's reforms.

\section{Determinants Risk Factors of Catastrophic Out-of-Pocket Health Expenditures}

The risk factors that may have an impact on catastrophic health expenditures are interpreted for different fixed and variable catastrophic thresholds by using binary logistic 
regression models. Since there is no high level of inter-correlation among the explanatory variables, all of the variables across the study years, were used in the model. In both models, results of logistic regression have given with "odd ratios", so prediction of the result considered as probability of incurring catastrophic health expenditures. Catastrophic health expenditures were found to be statistically significantly associated with nearly all the variables.

\section{Table: 11}

\section{Estimation Results of The Logistic Models for Different Fixed Catastrophic Threshold/Cut-Off Levels}

\begin{tabular}{|c|c|c|c|c|c|c|c|c|}
\hline \multirow{4}{*}{$\begin{array}{l} \\
\text { Explanatory Variables } \\
\text { Years } \\
(2002=\text { Ref.) }\end{array}$} & \multicolumn{8}{|c|}{ Dependent variables } \\
\hline & \multicolumn{8}{|c|}{ Presence of Catastrophic Health Expenditures for Different Fixed Thresholds } \\
\hline & \multicolumn{2}{|c|}{ cata $\geq 40 \%$} & \multicolumn{2}{|c|}{ cata $\geq 30 \%$} & \multicolumn{2}{|c|}{ cata $\geq 20 \%$} & \multicolumn{2}{|c|}{ cata $\geq 10 \%$} \\
\hline & Odds ratio & $\begin{array}{c}\text { R.St. } \\
\text { err }\end{array}$ & Odds ratio & R St. err & Odds ratio & R. St. err & Odds ratio & R. St. err \\
\hline 2004 & 0.798 & 0.263 & 0.709 & 0.163 & $0.548 * * *$ & 0.086 & $0.454 * * *$ & 0.046 \\
\hline 2006 & 0.753 & 0.209 & $0.600 * *$ & 0.121 & 0.859 & 0.105 & 0.981 & 0.073 \\
\hline 2008 & $0.616^{* *}$ & 0.142 & $0.658^{*} * *$ & 0.100 & $0.653 * * *$ & 0.068 & $0.653 * * *$ & 0.043 \\
\hline 2010 & 0.561 & 0.267 & $0.588^{*}$ & 0.087 & 0.728 & 0.140 & 0.854 & 0.099 \\
\hline 2012 & $0.256^{* * * *}$ & 0.076 & $0.330^{* * * *}$ & 0.061 & $0.498 * * *$ & 0.054 & $0.629 * * *$ & 0.040 \\
\hline 2014 & 0.609 & 0.148 & 0.578 & 0.0 .91 & $0.653^{* *}$ & 0.067 & $0.835 * * *$ & 0.051 \\
\hline 2016 & $0.706 * *$ & 0.150 & $0.596 *$ & 0.083 & $0.763 *$ & 0.071 & $0.936^{* * *}$ & 0.069 \\
\hline \multicolumn{9}{|l|}{ Gender of HH Head } \\
\hline Female $=1$ Male & 0.804 & 0.139 & 0.948 & 0.123 & 0.892 & 0.082 & 0.989 & 0.058 \\
\hline \multicolumn{9}{|l|}{ Insurance Type of HH Head } \\
\hline Public & \multicolumn{2}{|c|}{ Ref. $=1$} & \multicolumn{2}{|c|}{$\operatorname{Ref}=1$} & \multicolumn{2}{|c|}{ Ref. $=1$} & \multicolumn{2}{|c|}{ Ref. $=1$} \\
\hline Private & 1.257 & 0.443 & 1.111 & 0.273 & 1.190 & 0.194 & 1.134 & 0.122 \\
\hline Green Card & $2.576^{* * * *}$ & 0.570 & $1.927 * * * *$ & 0.298 & $1.536^{* * * *}$ & 0.163 & $1.418 * * *$ & 0.097 \\
\hline Non- Insurance & $2.484 * * *$ & 0.406 & $1.824 * * *$ & 0.214 & $1.606^{* * * *}$ & 0.130 & $1.476 * * *$ & 0.079 \\
\hline \multicolumn{9}{|l|}{ Education level of HH Head } \\
\hline Primary or less & \multicolumn{2}{|c|}{ Ref. $=1$} & \multicolumn{2}{|c|}{ Ref. $=1$} & \multicolumn{2}{|c|}{ Ref. $=1$} & \multicolumn{2}{|c|}{ Ref. $=1$} \\
\hline Secondary & $0.598 * * *$ & 0.127 & $0.552^{* * * *}$ & 0.084 & $0.716^{* * *}$ & 0.067 & $0.837 * * *$ & 0.046 \\
\hline Tertiary or high & $0.384 * * *$ & 0.116 & $0.489^{* * * *}$ & 0.095 & $0.662 * *$ & 0.079 & $0.883 * * *$ & 0.056 \\
\hline \multicolumn{9}{|l|}{ Mental or Physical Disability of HH Head } \\
\hline No=Ref. Yes & 1.390 & 0.346 & $1.498 * *$ & 0.251 & $1.697 * * *$ & 0.190 & $1.780 * * *$ & 0.128 \\
\hline \multicolumn{9}{|l|}{ Employment Status in The Main Job of HH Head } \\
\hline Unemployed & Ref.1 & & $\operatorname{Ref}$ & & $R e$ & & & \\
\hline Regular employee & $0.673 * *$ & 0.128 & $0.643 * * *$ & 0.084 & $0.805^{* *}$ & 0.068 & 0.910 & 0.048 \\
\hline Casual employee & 0.777 & 0.207 & 0.772 & 0.146 & 0.824 & 0.107 & 0.940 & 0.077 \\
\hline Employer & 0.794 & 0.419 & 1.158 & 0.347 & 1.070 & 0.215 & 0.902 & 0.115 \\
\hline Self-employed & $0.609^{* *}$ & 0.412 & $0.755^{* *}$ & 0.114 & 0.909 & 0.088 & 1.018 & 0.061 \\
\hline Unpaid family worker & 0.966 & 0.199 & 0.933 & 0.140 & 1.038 & 0.111 & 1.071 & 0.79 \\
\hline Settlement & & & & & & & & \\
\hline Rural=1 Urban & $1.649^{* * * *}$ & 0.244 & $1.433^{* * * *}$ & 0.150 & $1.376 * * *$ & 0.097 & $1.272 * * *$ & 0.058 \\
\hline Household Size & $0.816^{* * * *}$ & 0.033 & $0.883^{* * * *}$ & 0.023 & $0.935 * * *$ & 0.015 & $0.967 * *$ & 0.010 \\
\hline Having Elderly Member $(+65$ age) & & & & & & & & \\
\hline $\mathrm{No}=$ Ref. Yes & $1.954 * * *$ & 0.278 & $1.735 * * *$ & 0.172 & $1.645 * * *$ & 0.111 & $1.555 * * *$ & 0.068 \\
\hline Having Preschool Aged Child (Under 5 age) & & & & & & & & \\
\hline No=Ref. Yes & $1.624 * * *$ & 0.257 & $1.317 * *$ & 0.145 & $1.164 * *$ & 0.084 & $1.265 * * *$ & 0.055 \\
\hline Household Expenditures Quirtile & & & & & & & & \\
\hline Poorest & Ref.= & & Ref & & $\operatorname{Re}$ & & & \\
\hline Q2 & 0.891 & 0.180 & 0.934 & 0.126 & 1.019 & 0.090 & 1.049 & 0.060 \\
\hline Q3 & 1.291 & 0.251 & 1.091 & 0.148 & 1.108 & 0.100 & $1.166^{* * * *}$ & 0.068 \\
\hline Q4 & 0.933 & 0.211 & 0.948 & 0.141 & 0.928 & 0.091 & $1.192 * * *$ & 0.072 \\
\hline Richest & $2.727 * * *$ & 0.543 & $1.910 * * *$ & 0.269 & $1.367 * * *$ & 0.136 & $1.408 * * *$ & 0.090 \\
\hline Constant & $0.006^{* * * *}$ & 0.001 & $0.016^{* * * *}$ & 0.003 & $0.030 * * *$ & 0.004 & $0.062 * * *$ & 0.005 \\
\hline Log likelihood & -1558. & & -294 & & -580 & 4.71 & -122 & 1.06 \\
\hline $\mathrm{LR} \mathrm{chi}^{2}$ (d.f) & 304.29 & & 382.9 & (26) & 434.4 & $(26)$ & 544.1 & $5(26)$ \\
\hline Prob $>$ chi $^{2}$ & 0.00 & & 0.0 & & 0.0 & & & \\
\hline Pseudo $\mathrm{R}^{2}$ & 0.08 & & 0.0 & & 0.0 & & & \\
\hline Number of obs. & 7749 & & 774 & & 77 & & & \\
\hline
\end{tabular}


Manavgat, G. \& F. Saygıl1 \& M. Audibert (2020), "Examining the Economic Burden of Out-of-Pocket Health Expenditures for Households in Different Socio-Economic Groups in Turkey”, Sosyoekonomi, Vol. 28(46), 25-49.

When considering the different fixed thresholds $(10 \%, 20 \%, 30 \%$ and $40 \%)$, the probability of households incurred catastrophic health expenditures did not decrease statistically significant after 2003 HTP (Table 11). However, the probability of catastrophic health expenditure for all thresholds showed a statistically significant decrease in 2008 and 2016. The most significant decrease in catastrophic expenditures is in the level of $20 \%$ and $10 \%$.

The gender of the head of household is not a significant risk factor in catastrophic expenditure. Health insurance type of household head is closely related with incurring catastrophic expenditures. As expected, having no insurance is a risk factor for catastrophic health expenditures and also probability of incurring catastrophic spending is significantly higher than having Public Insurance. Households having no insurance face between 2.4 and 1.4 times more catastrophic health spending than household having Public Insurance. Also having a Green Card scheme (generally poor households hold it) may also affect on catastrophe compering with Public Insurance. Green Card holders are more likely to face catastrophic spending than Public Insurance-owned households. This finding indicates that the reform of restructuring health insurance scheme with HTP, Green Card holders continue to be included in the disadvantaged group in terms of insurance coverage. In this context, reforms undertaking within the scope of health insurance schemes have not provided sufficient success against the financial burden of OOP health expenditures. With other words, reorganization across health insurance scheme during healthcare reforms has been not successful enough for protection against financial burden in Turkey. The risk of catastrophic health payment is significantly higher in households with less educated, having elder members and having pre-school age children for all thresholds. The higher the education level, the lower the probability is, possibly reflecting better health status of educated households. In accordance with priori expectations, having mental or physical disability to work of household head are more likely to incur catastrophic health expenditure for all threshold (exception 10\%) levels. Households having mental or physical disability face between 2.0 and 1.5 times more in catastrophic health expenditures. Unemployed household heads are more likely to have catastrophic health expenditure for all thresholds (exception 10\%). Households head in any job risk of catastrophic health expenditure decrease according to the other employment position, but only among the regular employees are statistically significant. The probability of having catastrophic health payments among households living in urban areas is 1.6 to 1.2 times higher than those living in rural areas. As household size increases, catastrophic health payment increases (Table 11).

Two results are contrary to expectations for different fixed thresholds: poor households are less probability to experience catastrophic health expenditure as compared to non-poor households at all fixed threshold levels. Nevertheless, when the threshold value is lowered, -when the share of out of pocket health expenditures falls in capacity to pay- the possibility of facing catastrophic health expenditures in poor households is approaching rich households. This result may be due to the assumption that tendency to spend the same rate of out-of-pocket health payment in capacity to pay for each socioeconomic group. On the other hand, it is assumed that the tendency of the rich to spend for health is the same proportion as the poor by using fixed thresholds. We also may suppose in this result that the 
rich tend to consume the costliest health services as they want the most high-tech healthcare. But if their health insurance does not cover all the cost that contributes to increase OOP until reach a relatively high proportion of their income.

The risk factors of catastrophic health expenditures have also been analysed at the variable threshold for different socioeconomic quintile. The logistic regression results are shown in Table 12.

Table: 12

Estimation Results of The Logistic Models for Variable Catastrophic Threshold/CutOff Level

\begin{tabular}{|c|c|c|c|c|}
\hline \multirow{4}{*}{$\begin{array}{l}\text { Explanatory Variables } \\
\text { Years }(2002=\text { Ref. })\end{array}$} & \multicolumn{4}{|c|}{ Dependent variables } \\
\hline & \multicolumn{4}{|c|}{ Presence of Catastrophic Health Expenditures for Variable Thresholds } \\
\hline & \multicolumn{2}{|c|}{$Q_{\text {icata }} \geq \mathbf{4 0 *} \mathrm{r}-\mathrm{Q}_{5} \mathrm{cata} \geq \mathbf{4 0}$} & \multicolumn{2}{|c|}{$Q_{1}$ cata $\geq 10-Q_{\text {icata }} \geq 10 * p$} \\
\hline & Odds ratio & Robust St. Err & Odds ratio & Robust St. Err \\
\hline 2004 & $0.662 * *$ & 0.142 & $0.536^{* * * *}$ & 0.070 \\
\hline 2006 & 0.787 & 0.126 & 0.968 & 0.093 \\
\hline 2008 & $0.689 * * *$ & 0.094 & $0.774 * * *$ & 0.064 \\
\hline 2010 & $0.598^{*}$ & 0.159 & 0.887 & 0.130 \\
\hline 2012 & $0.409 * *$ & 0.059 & $0.644 * * *$ & 0.053 \\
\hline 2014 & $0.660 * *$ & 0.089 & $0.872^{*}$ & 0.69 \\
\hline 2016 & $0.699 * *$ & 0.090 & $0.963^{*}$ & 0.075 \\
\hline \multicolumn{5}{|l|}{ Gender of HH Head } \\
\hline Female $=1$ Male & 0.926 & 0.103 & 1.008 & 0.072 \\
\hline \multicolumn{5}{|l|}{ Insurance Type of HH Head } \\
\hline Public & \multicolumn{2}{|c|}{ Ref. $=1$} & \multicolumn{2}{|c|}{ Ref. $=1$} \\
\hline Private & 1.165 & 0.265 & 1.133 & 0.148 \\
\hline Green Card & $1.549 * * *$ & 0.189 & $1.443 * * *$ & 0.111 \\
\hline Non- Insurance & $1.536 * * *$ & 0.160 & $1.469 * * *$ & 0.094 \\
\hline \multicolumn{5}{|l|}{ Education level of HH Head } \\
\hline \multicolumn{5}{|l|}{ Primary or less } \\
\hline Secondary & $0.712 * * *$ & 0.093 & $0.769^{* * * *}$ & 0.058 \\
\hline Tertiary or high & $0.382 * * *$ & 0.091 & $0.697 * * *$ & 0.074 \\
\hline \multicolumn{5}{|l|}{ Mental or Physical Disability of HH Head } \\
\hline No=Ref. Yes & $1.687 * * *$ & 0.266 & $1.805^{* * * *}$ & 0.166 \\
\hline \multicolumn{5}{|l|}{ Employment Status in the Main Job of HH Head } \\
\hline Unemployed & \multicolumn{2}{|c|}{$\operatorname{Ref}=1$} & \multicolumn{2}{|c|}{ Ref. $=1$} \\
\hline Regular employee & $0.655^{* * * *}$ & 0.739 & $0.838 * *$ & 0.057 \\
\hline Casual employee & $0.756^{*}$ & 0.116 & 0.921 & 0.088 \\
\hline Employer & $0.491 *$ & 0.205 & 1.089 & 0.185 \\
\hline Self-employed & 0.836 & 0.104 & 1.063 & 0.079 \\
\hline Unpaid family worker & 0.880 & 0.110 & 1.039 & 0.090 \\
\hline \multicolumn{5}{|l|}{ Settlement } \\
\hline Rural=1 Urban & $1.502 * * *$ & 0.128 & $1.340^{* * * *}$ & 0.074 \\
\hline Household Size & $0.929 * * *$ & 0.019 & $0.962 * * *$ & 0.125 \\
\hline \multicolumn{5}{|l|}{ Having Elderly Member $(+65$ age $)$} \\
\hline No= Ref. Yes & $1.696 * * *$ & 0.140 & $1.614 * * *$ & 0.085 \\
\hline \multicolumn{5}{|l|}{ Having Preschool Aged Child (Under 5 age) } \\
\hline No=Ref. Yes & $1.122 * *$ & 0.111 & $1.262 * * *$ & 0.068 \\
\hline \multicolumn{5}{|l|}{ Household Expenditures Quintile } \\
\hline Poorest & \multicolumn{2}{|c|}{ Ref. $=1$} & \multicolumn{2}{|c|}{ Ref. $=1$} \\
\hline Q2 & $0.692 * * *$ & 0.067 & $0.831 * * *$ & 0.051 \\
\hline Q3 & $0.562 * * *$ & 0.061 & $0.691 * * *$ & 0.465 \\
\hline Q4 & $0.333 * * *$ & 0.046 & $0.553 * * *$ & 0.041 \\
\hline Richest & $0.439 * * *$ & 0.063 & $0.400^{* * * *}$ & 0.036 \\
\hline Constant & $0.031 * * *$ & 0.004 & $0.056 * * *$ & 0.005 \\
\hline Log likelihood & \multicolumn{2}{|c|}{-3760.23} & & .94 \\
\hline LR $\operatorname{chi}^{2}$ (d.f) & & $4(26)$ & & $(26)$ \\
\hline Prob $>\mathrm{chi}^{2}$ & & & & \\
\hline Pseudo $\mathrm{R}^{2}$ & & & & \\
\hline Number of obs. & & & & \\
\hline
\end{tabular}


Manavgat, G. \& F. Saygıl1 \& M. Audibert (2020), "Examining the Economic Burden of Out-of-Pocket Health Expenditures for Households in Different Socio-Economic Groups in Turkey”, Sosyoekonomi, Vol. 28(46), 25-49.

Thus, results from the fixed threshold are compared with the variable threshold. After HTP in Turkey, households are less likely to be in catastrophic health expenditures. However, it has increased slightly in recent years. The probability of catastrophic health expenditure increases among households uninsured, less educated, unemployed and having mental and physical disability member. Similar to the results of the analysis for fixed thresholds, the probability of catastrophic health expenditure increases among households having elderly member, pre-school aged children and household's residence in urban. However, the only difference from the two analyses (fixed and variable thresholds) are that the risk of incurring catastrophic health expenditure significantly increases among poor households. The probability of catastrophic health expenditures is pro-poor results in the approach which allows to change threshold for different socioeconomic groups. When the food expenditure rate indexed to the richest is used as weight, the threshold for the poor is getting lower or vice versa. Thus, in fact that, the probability of incurring catastrophic expenditures is higher among poor and it is statistically significant -contrary to the analysis results done by standard fixed threshold methods for Turkey-.

\section{Discussion}

In this study, catastrophic impacts of OOP health spending in Turkey have been analysed from the viewpoint of HTP and recent health policies. For this, we first used fixed thresholds based on the "capacity to pay" approach which is common method of previous studies. On the other side, the prevalence of catastrophic health expenditures was tried to be determined at variable thresholds between different socioeconomic groups. Using fixed threshold for different economic groups might be misunderstood in terms of assuming the same utility of last unit spent or marginal utility of money. We focused on how the ratio changes when household face catastrophic health expenditure using both the fixed threshold and the variable threshold level. As a matter of fact, in our analysis, we have caught some differences by following Onoka et al. (2011).

The share of OOP health expenditures in total expenditure and capacity to pay of households was examined during 2002-2016. This rate has generally increased somewhat. When look on the share of out of pocket health payments for the poor and the rich, the share of out-of-pocket health payments in total expenditures is lower in households in the poorest quintile. In 2014, the share of out of pocket health expenditures in the poorest group increased by about $40 \%$ compared to 2002 and by about $10 \%$ in the richest group. Yardim et al. (2014) showed that a slight decrease in the share of OOP health spending among the richest and a gradual increase towards the poorest.

Analysis results made by taking into account the share of OOP health expenditures in capacity to pay and total expenditures across insurance scheme are shown that there is a slight increase in OOP health payments for those holding Public Insurance. Particularity, the share of OOP health spending has decreased among households having Green Card that disadvantaged socioeconomic groups or poor, but still the share of out-of-pocket health payment is higher than Public Insurance holders. In 2003, the Green Card scheme covered only $3-6 \%$ of the population of Turkey. The expansion of benefits was accompanied by rapid 
Manavgat, G. \& F. Sayg1l \& M. Audibert (2020), "Examining the Economic Burden of Out-of-Pocket Health Expenditures for Households in Different Socio-Economic Groups in Turkey”, Sosyoekonomi, Vol. 28(46), 25-49.

expansion in 2004-05 of the number of Green Card beneficiaries that almost quadrupled from 2-4 million people in 2003 to $8-3$ million in 2005, then increased to around $10 \cdot 2$ million people by 2011 , which accounted for $13 \cdot 8 \%$ of the total population (Atun et al., 2013). On the other hand, Green Card benefits were expanded to include access to outpatient services and drugs and aligned with benefits offered by other health insurance schemes, with rapid expansion of coverage in the uninsured poor population after in 2004, and management of the Green Card scheme undertook to SSI in 2012. Despite these positive enhancements, the economic burden of health spending is higher among the Green Card holders than the SSI or Public Insurance holders. A similar finding is found by Erus and Aktakke (2012), rich households with public insurance had a greater decline in the share out-of -pocket payment in total expenditures.

Prevalence of catastrophic health expenditures among households has shown a gradual decline from 2002 to 2016 for the fixed threshold at $10 \%$ of level. Households which account for $40 \%$ or more of the capacity to pay for OOP health spending have a decrease in the study period. The proportion of household incurred catastrophic health expenditure is below $1 \%$ at this fixed threshold. The proportion of households faced with catastrophic health spending decreased for the variable threshold level of $\% 10$ indexed poorest. The percentage of household in catastrophic health expenditure is almost half the lower $(<$ to $4.5 \%$ ) at variable threshold level of $10 \%$ than fixed threshold level of $10 \%$. The proportion of households faced with catastrophic health spending exceeds $1 \%$ at the variable threshold level of $40 \%$ indexed richest contrary to the fixed threshold level of $40 \%$. It has been determined that the results are different when variable threshold approach is used for different socioeconomic groups. So as follow Onoka et al. (2011), it might be using the same threshold for all households irrespective of the income or its proxy is inappropriate as a way of judging the impact of expenditure on the well-being of households of different socioeconomics group.

Results of binary logistic regression models are shown that with a fixed threshold, contrary to expectations, poor household have less likely in catastrophic expenditure. Conversely, the results with the variable threshold showed that the poor were more likely to have catastrophic health expenditures. In many studies this finding explains that poor households are either avoiding health spending or not seeking healthcare behaviour, so poor are less likely to have catastrophic health payment because of lack of expenditures. As indicated Somkotra and Lagrada (2009), the health service provided by private health facilities that are more costly is related to a voluntary preference and therefore the poor cannot make these expenditures lack of low purchasing power. In addition, Wagstaff and Lindelow (2008) and Brown et al. (2014) show that, having insurance may increase the demand of healthcare, an increasing demand can also lead to higher OOP health payment. For this reason, contracting private healthcare institutions in public insurance system, can lead to the burden of health expenditures of households due to private sector profit motive. As a matter of fact, since 2005 private health institutions and social security institutions have made contracting for health service procurement in Turkey. The registered in the social security institution can receive services from the private sector. The state pays some of this cost. With this regulation, non-poor groups who can afford to pay extra charge have been 
Manavgat, G. \& F. Saygilı \& M. Audibert (2020), "Examining the Economic Burden of Out-of-Pocket Health Expenditures for Households in Different Socio-Economic Groups in Turkey”, Sosyoekonomi, Vol. 28(46), 25-49.

able to benefit more from private healthcare facilities. Non-poor household incurred more in catastrophic health expenditures at fixed threshold can explain with this logical conclusion.

On the other side, if the variable threshold approach for different socioeconomic groups is taken into account in the logistic regression, the findings show that the poor are more likely to incur catastrophic health expenditures. This result suggests that the threshold to be determined catastrophically may be due to the fixed use for different socioeconomic groups rather than the interpretation that the poor can't pay health care or do not prefer to private health care facilities. When fixed thresholds are considered among households with different economic situation, it might mislead to think that the share of health expenditures in capacity to pay is also the same. Our findings seem to confirm this variable threshold method.

The other variable that used in binary logistic model results did not show much difference in terms of significance and probability value. The probability of incur to catastrophic health expenditure among Green Card holders and uninsured households is much higher for both the fixed threshold and the variable threshold. Having under Public Insurance is important to protect against financial burden. Green Card or General Health Insurance scheme regulations for poorer individuals that have expanded coverage in health care reform seem to be very limited in terms of financial protection.

Risk of catastrophic health care is significantly higher among households in less educated, having elderly member and those with children under 5 years, regardless of the threshold value. These findings suggest that healthcare policy especially for elderly people is important. Previous studies have also shown that the probability of exposure to catastrophic health expenditures is higher in those with chronic diseases, disabled and acute illnesses (Su et al., 2006; Ruger \& Kim, 2007). In Turkey, adults have chronic disease or disability in excess of half the population aged 60 years and over. According to the World Value Survey (WVS) data, in Turkey, one third elderly participants are to define their health status as weak and inadequate (WVS-Wave 6, 2010-2014). On the other hand, according to TURKSTAT "Population Projection (2013)" in Turkey, the population is expected to age rapidly (proportion of population over 65 years will increase from $7.5 \%$ to $10.2 \%$ in 2023 ). It cannot be said that there is still yet a certain policy regarding aged health care services. The Turkish health system is currently devoid of certain elderly care services (long-term care services) that can be covered under existing insurance. Elderly long-term care reforms have come into question with HTP, but the quantity and quality of elderly health care providers are still insufficient. The increase in the risk of catastrophic health expenditure among households having disabled member reveals that underlines the need for considering of OOP health payments for inpatient treatment. Actually, the type of disability is also important to incur catastrophic health expenditures (Lee et al., 2016). Unluckily, the status of persons with disabilities is not specifically available in HBS, so that it is not possible comprehensive analysis. 
In addition, the unemployment of the head of household increases the risk of catastrophism significantly. The catastrophe risk is decreasing in the households those household head work in any job, but the catastrophic health expenditures is shown a statistically significant decline among only regular income employees. Among the employees, the likelihood of catastrophic health expenditures for the self-employed and unpaid family workers does not decrease significantly. It is well known that the poverty rate is high, especially among self-employed and unpaid family workers in Turkey. Unpaid family workers are not considered as insured or not registered social security. Our finding reveals that financial burden of OOP payments risk is high for this group. This finding shows that it requires the assessment of policies for the cover of social security insurance among employed in any job. Because working doesn't protect enough against the catastrophic health expenditures for some groups.

\section{Conclusion}

The use of health services became widespread and the proportion of the population covered by insurance increased with the health policies recently implemented in Turkey. On the other side, policies to influence social benefits have come to the fore with the expansion of private health institutions and the commercialization of healthcare services profit. These enhancements have had a limited impact on the financial burden of out-of-pocket health expenditures of households. With using private healthcare service through social security contracts, which means passive privatization and reimbursement and co-payment implications, non-poor households that can afford health payments have more benefited in Turkey. Unlike many previous studies, this study has shown the poor have higher probability of incurring financial burden of out-of-pocket health expenditures. The reason for this is that the fixed threshold value has been used for different socioeconomic groups in previous studies. The existence of high levels of catastrophic expenditure amongst households have generally reduced with HTP, but the risks of disadvantaged groups are still high. Although the problems of measuring the financial burden of health expenditures continue to be discussed, the results that we have obtained from this new method contribute to the expansion of the discussion area for health economics and social policies in Turkey.

\section{References}

Adisa, O. (2015), "Investigating Determinants of Catastrophic Health Spending Among Poorly Insured Elderly Households in Urban Nigeria", International Journal for Equity in Health, 14(1), 79.

Aran, M.A. \& J.S. Hentschel (2012), "Protection in Good and Bad Times? The Turkish Green Card Health Program", Policy Research Working Paper 6178, The World Bank, <http://documents.worldbank.org/curated/en/258701468172771874/pdf/wps6178.pdf>, 25.09.2017.

Arsenijevic, J. \& M. Pavlova \& M. Groot (2013), "Measuring the catastrophic and impoverishing effect of household health care spending in Serbia", Social Science and Medicine, (78), $17-25$. 
Manavgat, G. \& F. Saygıl1 \& M. Audibert (2020), "Examining the Economic Burden of Out-of-Pocket Health Expenditures for Households in Different Socio-Economic Groups in Turkey”, Sosyoekonomi, Vol. 28(46), 25-49.

Atun, R. \& S. Aydın \& S. Chakraborty \& S. Sumer \& M. Aran \& I. Gurol \& S. Nazlıŏlu \& S. Ozgulcu \& U. Aydoğan \& B. Ayar \& U. Dilmen \& R. Akdağ (2013), "Universal Health Coverage in Turkey: Enhancement of Equity", The Lancet, <https://doi.org/10.1016/S0140-6736(13)61051-X>, 25.09.2017.

Aykaç, G. (2018), “Engel Yasası’nın Türkiye Sınaması ve Gıda Talebinin Gelir Esnekliği: Gıda Harcamalarının Bütçe Payının Hane Profili ve Toplam Harcama ile İlişkisi (2003-2013)”, Sosyoekonomi, 26(38), 105-133.

Berki, S.E. (1986), “A Look at Catastrophic Medical Expenses and The Poor”, Health Affairs, 5(4), 139-145.

Brown, S. \& A.R. Hole \& D. Kilic (2014), "Out-Of-Pocket Health Care Expenditure in Turkey: Analysis of the 2003-2008: Household Budget Surveys", Economic Modelling, (41), 211-218.

Ekman, B. (2004), "Community-Based Health Insurance in Low-Income Countries: A Systematic Review of The Evidence", Health Policy Plan, 19(5), 249-70.

Erus, B. \& N. Aktakke (2012), "The Impact of Healthcare Reforms on Out-Of-Pocket Health Expenditures in Turkey For Public Insurance", European Journal of Health Economics, 13(3), 337-346.

Gotsadze, G. \& A. Zoidze \& N. Rukhadze (2009), "Household Catastrophic Health Expenditure: Evidence from Georgia And Its Policy Implications", BMC Health Services Research, 9(69), 1-9.

Goudge, J. \& S. Russell \& L. Gilson \& C. Molyneux \& K. Hanson (2009), "Household Experiences of Ill-Health and Risk Protection Mechanisms", Journal of International Development, 21, 159-168.

Kim, Y. \& B. Yang (2011), "Relationship between Catastrophic Health Expenditures and Household Incomes and Expenditure Patterns in South Korea”, Health Policy, (100), 239-246.

Lee, J.E. \& H.I. Shin \& Y.K. Do \& E.J. Yang (2016), "Catastrophic Health Expenditures for Households with Disabled Members: Evidence from the Korean Health Panel", Journal of Korean Medical Science, 31(3), 336-344.

Minh, H.V. \& N.T.K. Phuong \& P. Saksena \& D.C. James \& K. Xu (2013), "Financial Burden of Household Out-Of Pocket Health Expenditure in Vietnam: Findings from the National Living Standard Survey 2002-2010", Social Science and Medicine, (96), 258-263.

Ministry of Health (2015), Annual Health Statistics, <http://www.saglikistatistikleri.gov.tr/dosyalar/SIY_2015.pdf>, 27.09.2018.

Onoka, A.C. \& O.E. Onwujekwe \& K. Hanson \& B.S. Uzochukwu (2011), "Examining Catastrophic Health Expenditures at Variable Thresholds Using Household Consumption Expenditure Diaries", Tropical Medicine and International Health, 16(10), 1334-1341.

Ozgen, N.H. \& İ. Sahin \& H.H. Yıldırım (2015), "Financial Catastrophe and Poverty Impacts of Outof-Pocket Health Payments in Turkey", European Journal of Health Economics, 16(3), 255-270.

Ruger, R. \& H.J. Kim (2007), “Out-of-Pocket Healthcare Spending by the Poor and Chronically Ill in The Republic of Korea”, American Journal of Public Health, 97(5), 804-811.

Somkotra, T. \& L.P. Lagrada (2009), "Which Households Are at Risk of Catastrophic Health Spending: Experience in Thailand After Universal Coverage?", Health Affairs, 28(3), 467-478. 
Manavgat, G. \& F. Sayg1l \& M. Audibert (2020), "Examining the Economic Burden of Out-of-Pocket Health Expenditures for Households in Different Socio-Economic Groups in Turkey", Sosyoekonomi, Vol. 28(46), 25-49.

Su, T. \& B. Kouyaté \& S. Flessa (2006), "Catastrophic Household Expenditure for Health Care in A Low -Income Society: A Study from Nouna District Burkina Faso", Bulletin of the World Health Organization, 84(1), 21-27.

Sulku, S.N. \& D. Bernard (2012), "Financial Burden of Health Care Expenditures: Turkey", Iranian Journal of Public Health, 41(3), 48-64.

Tokatlığlı, İ. \& Y. Tokatlığlu (2014), “Türkiye'de 2002-2011 Yılları Arasında Katastrofik Sağlık Harcamalarının Yoksulluk Yaratma Kapasitesi”, Ekonomik Yaklaşım, 24(87), 1-36.

Tokatlığlı, Y. \& İ. Tokatlığlu (2018), “Türkiye'de Katastrofik Sağlık Harcamaları ve Bu Harcamaları Belirleyen Faktörler: 2002-2014 Dönemi”, Sosyoekonomi, 26(35), 59-78.

TurkStat Turkish Statistical Institute (2002-2014), Household Budget Survey Micro Data Set, <http://www.tuik.gov.tr/Kitap.do?metod=KitapDetay\&KT_ID=7\&KITAP_ID=312>, 23.09.2018.

TurkStat Turkish Statistical Institute (2003), Based Consumer Price Index Numbers, <http://www.turkstat.gov.tr/UstMenu.do?metod=temelist>, 22.08.2018.

TurkStat Turkish Statistical Institute (2013), Population Projections 2013-2075, <http://www.turkstat.gov.tr/PreHaberBultenleri.do?id=15844>, 23.09.2018.

TurkStat Turkish Statistical Institute (2016), Health Expenditure Statistics, <http://www.tuik.gov.tr/PreTablo.do?alt_id=1084>, 23.09.2018.

van Doorslaer, E. \& O. O’Donnell \& R.P. Rannan-Eliya \& P. Somanathan \& S.H. Adhikari \& B. Akkazieva \& D. Harbianto \& C.G. Garg \& P. Hanvoravongchai \& A.N. Herrin \& M.N. Huq \& S. Ibragimova \& A. Karan \& T.J. Lee \& G.M. Leung \& J.R. Lu \& C.W. Ng \& B.R. Pande \& R. Racelis \& S. Tao \& K. Tin \& L. Trisnantoro \& C. Vasavid \& B.M. Yang \& Y. Zhao (2007), "Catastrophic Payments For Health Care in Asia", Health Economics, 16(11), 1159-84.

Wagstaff, A. \& E. van Doorslaer, (2003), "Catastrophe and Impoverishment in Paying for Health Care: With Applications to Vietnam 1993-98”, Health Economics, 12(11), 921-34.

Wagstaff, A. \& M. Lindelow (2008), "Can Insurance Increase Financial Risk? The Curious Case of Health Insurance in China”, Journal of Health Economics, 27, 990-1005.

WHO World Health Organization (2000), World Health Report 2000, Health Systems: Improving Performance?, Geneva, <http://www.who.int/whr/2000/en/whr00_en.pdf?ua=1>, 15.09.2017.

WHO World Health Organization (2005), "Social Health Insurance: Sustainable Health Financing, Universal Coverage and Social Health Insurance", Report by the Secretariat, A58/20, Provisional agenda item 13-16, <http://apps.who.int/iris/bitstream/10665/20302/1/A58_20-en.pdf?ua=1>, 27.09.2017.

World Bank (2016), Out-of-Pocket Expenditure (\% of current health expenditure) Statistics, $<$ https://data.worldbank.org/indicator/SH.XPD.OOPC.CH.ZS〉, 27.01.2020.

WVS World Values Survey Wave- 6 (2010-2014), State of health Stat., <http://www.worldvaluessurvey.org/WVSOnline.jsp>, 27.09.2018.

Xu, K. \& D.B. Evans \& K. Kawabata \& R. Zeramdini \& J. Klavus \& C.J. Murray (2003), "Catastrophic Health Expenditure: A Multicounty Analysis", The Lancet, 362(9378), 111-117.

Xu, K. \& D.B. Evans \& P. Kadama (2006), "Understanding the Impact of Eliminating User Fees: Utilization and Catastrophic Health Expenditures in Uganda", Social Science and Medicine, 62(4), 866-876. 
Xu, K. (2005), "Distribution of Health Payments and Catastrophic Expenditures Methodology”, World Health Organization, Department of Health System Financing, Discussion Paper: Number 2, Geneva, <http://www.who.int/health_financing/documents/dp_e_05_2distribution_of_health_pay ments.pdf>, 27.09.2018.

Yardım, M.S. \& N. Cilingiroglu \& N. Yardim (2010), "Catastrophic Health Expenditure and Impoverishment in Turkey”, Health Policy, 94(1), 26-33.

Yardim, M.S. \& N. Cilingiroglu \& N. Yardim (2014), "Financial protection in health in Turkey: the effects of the Health Transformation Programme", Health Policy and Planning, 29(2), 177-192.

Yereli, A.B. \& A.M. Köktaş \& I.S. Selçuk, (2014), “Türkiye'de Katastrofik Sağlık Harcamalarını Etkileyen Faktörler”, Sosyoekonomi, 22(22), 274-296. 
Manavgat, G. \& F. Saygılı \& M. Audibert (2020), "Examining the Economic Burden of Out-of-Pocket Health Expenditures for Households in Different Socio-Economic Groups in Turkey", Sosyoekonomi, Vol. 28(46), 25-49. 